\title{
Evaluation of hematological alteration of vector-borne pathogens in cats from Bangkok, Thailand
}

\author{
Thom Do, Ketsarin Kamyingkird, Wissanuwat Chimnoi and Tawin Inpankaew*
}

\begin{abstract}
Background: Cats can be carriers of infected arthropods and be infected with several vector-borne pathogens (VBPs) but there is limited knowledge about their pathogenic role in cats. This study aimed to assess the prevalence of some feline vector-borne agents by molecular technique and to characterize the hematological findings associated with these infections in a cat population from Bangkok Thailand.

Results: PCR was positive with at least one pathogen in 237 out of 372 subjects (63.7\%), with prevalence of 39.5\% (147/372) for Babesia spp., 36.9\% (137/372) for hemoplasmas and 3.2\% (12/372) for Hepatozoon spp. The cats older than 1 year were at significantly greater risk for VBPs infection $(P=0.001 ; \mathrm{OR}=1.43 ; 95 \% \mathrm{Cl}: 1.12-1.81)$ and hemoplasmas infection ( $X 2=10.8, \mathrm{df}=1 ; P<0.0001 ; \mathrm{OR}=2.45 ; 95 \% \mathrm{Cl}: 1.49-4.01)$. A significant association between hematological findings and hemoplasma infection were identified in the present study. Besides, VBPs infection revealed more frequent in male cats $(x 2=6.38, \mathrm{df}=1, P=0.01)$. Macrocytic hypochromic type of anemia was observed in cats infested with blood-sucking arthropods compared to the non-infested cats presented.
\end{abstract}

Conclusions: The current study confirmed that Babesia, Hepatozoon and hemoplasmas had infected semidomesticated cats in Bangkok, Thailand, with Babesia and hemoplasmas being dominant in prevalence. Some hematological findings were significantly associated with cats infected with vector-borne pathogens in this study including leukocyte count and platelets count that may help support veterinary technicians in diagnosis and appropriate treatment. Campaigns of VBPs monitoring in Bangkok emphasizing on the investigation of vectors and possible routes of the infection in animals should be conducted to prevent the transmission of the pathogens.

Keywords: Vector-borne pathogens, Babesia, Hepatozoon, Hemoplasmas, Hematological parameters, Semidomesticated cats

\section{Background}

Vector-borne pathogens (VBPs) can cause significant impact on the health status of various animals, human included, which are transmitted by a variety of vectors, such as ticks, flies, mosquitoes, fleas and etc. [1]. The most common vector-borne diseases in animals worldwide (predominantly in dogs and cats) are babesiosis,

\footnotetext{
*Correspondence: tawin.i@ku.th

Department of Parasitology, Faculty of Veterinary Medicine, Kasetsart University, 10900 Bangkok, Thailand
}

hepatozoonosis and hemoplasmosis which are caused by Babesia spp., Hepatozoon spp. and hemotropic mycoplasma, respectively [1]. Babesia and Hepatozoon, tickborne intracellular protozoan parasites and the hemotropic mycoplasma (hemoplasmas), a group of uncultivatable bacteria within the genus Mycoplasma are known as important causes of emerging and re-emerging illness in cats and can induce variable degrees of hemolytic anemia [2,3]. The clinical signs associated with these pathogens are often vague or non-specific and seem to

(c) The Author(s). 2021 Open Access This article is licensed under a Creative Commons Attribution 4.0 International License, which permits use, sharing, adaptation, distribution and reproduction in any medium or format, as long as you give appropriate credit to the original author(s) and the source, provide a link to the Creative Commons licence, and indicate if changes were made. The images or other third party material in this article are included in the article's Creative Commons licence, unless indicated otherwise in a credit line to the material. If material is not included in the article's Creative Commons licence and your intended use is not permitted by statutory regulation or exceeds the permitted use, you will need to obtain permission directly from the copyright holder. To view a copy of this licence, visit http://creativecommons.org/licenses/by/4.0/ The Creative Commons Public Domain Dedication waiver (http://creativecommons.org/publicdomain/zero/1.0/) applies to the data made available in this article, unless otherwise stated in a credit line to the data. 
be associated with fever, lethargy and anorexia in most cases [4].

Hematological alterations are indicators of several vector borne diseases and has been considered to be good tools to support practitioner for clinical diagnosis of VBPs infection which could reveal a wide range of different types of anemia in symptom $[5,6]$. Other hematological abnormalities such as leukopenia, leukocytosis and thrombocytopenia, have been sporadically documented in vector-borne pathogen infections in animals $[6,7]$. However, the association between these hematological parameters and vector-borne infection in cats in Thailand are limited.

In order to identify the specific pathogens in an infected animal currently, molecular testing has shown advantages of high specificity and sensitivity in being able to accurately identify and differentiate VBPs from others [4]. Research developments regarding molecular techniques in diagnosis have been rapidly applied in epidemiological investigation and have shown that the prevalence of VBPs based on Babesia, Hepatozoon and hemoplasmas in cats varies worldwide [4, 8-13].

In Bangkok, a myriad number of stray cats and dogs are allowed roaming the streets, public places and Buddhist monastery [14]. These animals were reported with a high prevalence $(90.0 \%)$ of flea, tick and lice infection and indicated to be potential sources for some vectorborne diseases $[15,16]$. Many communities in Thailand, owned cats are allowed to roam freely outdoors. Such a status can create a risk for human health, when they might contact with infected animals outside and bring infection into the home and transmit it directly to human. This study aimed to assess the prevalence of some feline vector-borne agents by molecular technique and to characterize hematological abnormalities associated with these infections in a cat population from central Thailand to provide additional support for veterinary technicians and veterinarians in diagnosis and treatment.

\section{Results}

\section{VBPs infection in cats}

Out of the 372 semi-domesticated cats, the overall prevalence of VBPs infection was 63.8\% (237/372). The prevalence of Babesia spp., Hepatozoon spp. and hemoplasmic DNA were 39.5\% (147/372), 3.2\% (12/372) and $36.9 \%$ (137/372), respectively. The details were presented in Table 1. Risk factor analysis of VBPs infection in cats showed that, the cats older than 1 year were at significantly greater risk for VBPs infection $(P=0.001$; OR $=$ 1.43; $95 \%$ CI: $1.12-1.81)$ and hemoplasmas infection $\left(\mathrm{X}^{2}=10.8, d f=1 ; P<0.0001 ; \mathrm{OR}=2.45 ; 95 \%\right.$ CI: 1.49 4.01). Similarly, the same result was also observed in cats older than 1 year for Babesia spp. and hemoplasmas coinfection $\left(X^{2}=5.53, d f=1, P=0.01\right)$. However, this was not the case for Babesia spp. $\left(\chi^{2}=0.81, d f=1, P=0.36\right)$ or Hepatozoon spp. $\left(\chi^{2}=0.006, d f=1, P=0.936\right)$ infection alone (Table 1 ). Some statistically significant associations between cat gender (male 46.0\%, female 54.0\%) and vector-borne prevalence were detected. Specifically, male cats were more likely to be infected with any VBPs $\left(\chi^{2}=6.38, d f=1, P=0.01\right)$ and with hemoplasmas $\left(\chi^{2}=\right.$ 7.29, $d f=1, P=0.006)$ compared to female cats. Male cats were 1.64 times (95\% CI: $1.06-2.54)$ and 1.84 times (95\% CI: $1.20-2.81$ ) at higher risk of infection from any VBPs and hemoplasmas, respectively (Table 1). Cats were visually inspected for ectoparasite infestation $(50.5 \%, 188 / 372)$. The species of ectoparasite presented in the study included Rhipicephalus sanguineus, Ctenocephalides felis felis and Felicola subrostratus. However, no significant differences in vector-borne prevalence were detected between ectoparasite infestations and non-ectoparasite infestations.

\section{Hematological findings}

In the current study, the majority of hematological findings of control groups have fallen between the normal ranges [15], except for WBC. The hematological findings revealed differences between the infected and control groups of cats in the WBC and PLTs parameters (Table 2). Specifically, there was a significant reduction $(P=0.04,95 \%$ CI: $0.02-3.35)$ in the number of leukocytes $(18.12 \pm 6.9)$ and a significant decrease in the number of thrombocytes $(394 \pm 148.4)$ of hemoplasmasinfected cats compared to non-infected cats $(19.68 \pm 8.7$; $438 \pm 169.3)$, respectively. A low number of thrombocytes were observed between the VBP-infected group (401.7 $\pm 146 ; P=0.03,95 \%$ CI: $2.75-71.54)$ and negative group (438 \pm 169.3$)$ but not infection alone with Babesia spp. ( $P=0.33,95 \%$ CI: $-16.21-47.5)$ or Hepatozoon spp. $(P=0.28$, 95\% CI: $-165.37-54.02)$. Some additional significant associations were detected between these hematological data and ectoparasite-infested prevalence in cats. Cats infested with ectoparasites showed a significant difference compared to non-infested cats regarding erythrocyte, hemoglobin value, $\mathrm{MCV}$ and $\mathrm{MCHC}$ values. Ectoparasite-infested cats showed macrocytic hypochromic anemia through an increase in the MCV (49.21 \pm $5.3)$ and a decline in the MCHC $(31.42 \pm 2.2)$ compared to the non-infested group $(P<0.001,95 \%$ CI: $0.29-1.12)$. Some other hematological abnormalities determined in cats infested with ectoparasites were a low number of erythrocytes (RBCs) $(P=0.04,95 \%$ CI: 0.004-0.59) and a low concentration of hemoglobin (HGB) $(P=0.0233$, 95\% CI: 0.06-0.93) (Table 2).

The study found that cats infected with at least one VBP represented 58.9\% (33/56) for anemia, 100\% (3/3) 
Table 1 Distribution of vector-borne infection in semi-domesticated cats based on epidemiological data

\begin{tabular}{|c|c|c|c|c|c|c|c|c|c|c|}
\hline \multirow[t]{2}{*}{ Variable } & \multirow{2}{*}{$\begin{array}{l}\text { Total } \\
\text { number }\end{array}$} & \multirow{2}{*}{$\begin{array}{l}\text { Number of negative } \\
\text { cats (\%) }\end{array}$} & \multicolumn{8}{|c|}{ Number of positive cats (\%) } \\
\hline & & & $\begin{array}{l}\text { Any } \\
\text { pathogen }\end{array}$ & $\begin{array}{l}\text { Babesia } \\
\text { spp. }\end{array}$ & $\begin{array}{l}\text { Hepatozoon } \\
\text { spp. }\end{array}$ & Hemoplasmas & $\begin{array}{l}\mathrm{BB}+ \\
\mathrm{HM}\end{array}$ & $\begin{array}{l}\text { BB + } \\
\text { HP }\end{array}$ & $\begin{array}{l}\mathrm{HM}+ \\
\mathrm{HP}\end{array}$ & $\begin{array}{l}\mathrm{BB}+ \\
\mathrm{HM}+\mathrm{HP}\end{array}$ \\
\hline & 372 & $135(36.3)$ & $237(63.8)$ & $147(39.5)$ & $12(3.2)$ & $137(36.9)$ & $\begin{array}{l}50 \\
(13.4)\end{array}$ & $3(0.8)$ & $6(1.6)$ & $2(0.5)$ \\
\hline \multicolumn{11}{|l|}{ Age } \\
\hline $\begin{array}{l}\text { Young ( } \leq 1 \text { - } \\
\text { year-old) }\end{array}$ & $81(21.8)$ & $42(51.9)$ & $39(48.1)$ & $13(16.1)$ & $2(2.5)$ & $14(17.2)$ & $4(4.9)$ & 0 & $1(1.2)$ & 0 \\
\hline $\begin{array}{l}\text { Adult (> 1- } \\
\text { year-old) }\end{array}$ & $291(78.2)$ & $93(32)$ & $198(68)^{*}$ & $134(46.1)$ & $10(3.4)$ & $123(42.3)^{*}$ & $\begin{array}{l}46 \\
(15.9)^{*}\end{array}$ & $3(1.0)$ & $5(1.7)$ & $2(0.7)$ \\
\hline \multicolumn{11}{|l|}{ Gender } \\
\hline Male & $171(46)$ & $49(28.7)$ & $122(71.3)^{*}$ & $73(42.7)$ & $6(3.5)$ & $76(44.4)^{*}$ & $29(17)$ & $2(1.2)$ & $3(1.8)$ & $1(0.6)$ \\
\hline Female & $201(54)$ & $86(42.8)$ & $115(57.2)$ & $74(37)$ & $6(3)$ & $61(30.3)$ & $\begin{array}{l}21 \\
(10.4)\end{array}$ & $1(0.5)$ & $3(1.5)$ & $1(0.5)$ \\
\hline \multicolumn{11}{|c|}{ Ectoparasite infestation } \\
\hline Yes & $188(50.5)$ & $67(35.6)$ & $121(64.4)$ & $82(44)$ & $10(5.3)$ & $65(35)$ & $\begin{array}{l}28 \\
(14.9)\end{array}$ & $3(1.6)$ & $5(2.7)$ & $2(1.0)$ \\
\hline No & $184(49.5)$ & $68(37)$ & $116(63)$ & $65(35.3)$ & $2(1.1)$ & $72(39.1)$ & $22(12)$ & $0(0.0)$ & $1(0.5)$ & $0(0.0)$ \\
\hline \multicolumn{11}{|c|}{ Tick infestation } \\
\hline Yes & $7(1.9)$ & $4(57.1)$ & $3(42.9)$ & $1(14.3)$ & 0 & $3(42.9)$ & $\begin{array}{l}1 \\
(14.3)\end{array}$ & 0 & 0 & 0 \\
\hline No & $365(98.1)$ & $247(67.7)$ & $118(32.3)$ & $81(22.2)$ & $10(2.7)$ & $62(17)$ & $\begin{array}{l}27 \\
(7.4)\end{array}$ & $3(0.8)$ & $5(1.4)$ & $2(0.5)$ \\
\hline \multicolumn{11}{|c|}{ Louse infestation } \\
\hline Yes & $8(2.2)$ & $4(50)$ & $4(50)$ & $3(37.5)$ & 0 & $2(25)$ & $\begin{array}{l}1 \\
(12.5)\end{array}$ & 0 & 0 & 0 \\
\hline No & $364(97.8)$ & $247(67.9)$ & $117(32.1)$ & $79(21.7)$ & $10(2.7)$ & $63(17.3)$ & $\begin{array}{l}27 \\
(7.4)\end{array}$ & $3(0.8)$ & $5(1.4)$ & $2(0.5)$ \\
\hline \multicolumn{11}{|c|}{ Flea infestation } \\
\hline Yes & $179(48.1)$ & $69(38.5)$ & $110(61.5)$ & $73(40.8)$ & $10(5.6)$ & $58(32.4)$ & $25(14)$ & $3(1.7)$ & $5(2.8)$ & $2(1.1)$ \\
\hline No & $193(51.9)$ & $182(94.3)$ & $11(5.7)$ & $9(4.7)$ & 0 & $7(3.6)$ & $3(1.6)$ & 0 & 0 & 0 \\
\hline
\end{tabular}

Abbreviations: BB Babesia spp, HM Hemoplasmas, HP Hepatozoon spp

*Statistically significant differences $(P<0.05)$

for leukopenia, 63.6\% (178/280) for leukocytosis and $63.6 \%(61 / 88)$ for thrombocytopenia. Hemoplasmas infection $(41.0 \%$; $23 / 56)$ was most frequent in anemic cats, followed by Babesia infection $(32.1 \% ; 18 / 56)$ and Hepatozoon infection $(3.6 \% ; 2 / 56)$. However, no significant associations were found between CBC abnormalities and vector-borne PCR-positive results (Table 3).

\section{Sequence analysis}

For each genus of VBP detected from the blood samples, positive amplicons were subjected to sequencing and BLAST analysis. All obtained sequence for each pathogen were found to share over $99.0 \%$ identity with reported Candidatus Mycoplasma haemominutum (GenBank accession numbers KR905451, KU645935), Candidatus Mycoplasma turicensis (GenBank accession numbers DQ464423, KR905458) and Mycoplasma hemofelis (Genbank accession numbers KU645929, KR905465). Regarding Babesia and Hepatozoon species, all positive amplicons share $99.7 \%-100 \%$ sequence identity with isolates of Babesia vogeli (GenBank accession numbers MN823219) and Hepatozoon canis (Genbank accession numbers KU765201), respectively.

\section{Discussion}

The presence of Babesia, Hepatozoon and hemotropic mycoplasma (generally called VBPs) infections in the cats from Bangkok, Thailand was demonstrated in this study. Our results showed that the most prevalent pathogens were Babesia and and hemoplasma whereas Hepatozoon. was less frequently detected. The overall prevalence of Babesia (39.5\%; 147/372) infection in the cats in the current study was higher than the results of a previous study carried out in Thailand over a decade ago, where infection was $1.4 \%$ in a population of 1,490 
Table 2 Selected hematological findings on vector-borne pathogens PCR-positive cats and PCR-negative cats and of ectoparasitic infestation and ectoparasitic non-infestation in cats

\begin{tabular}{|c|c|c|c|c|c|c|c|}
\hline \multirow{2}{*}{$\begin{array}{l}\text { Hematological } \\
\text { parameters }\end{array}$} & \multirow{2}{*}{$\begin{array}{l}\text { Negative } \\
\text { cats - Mean } \\
( \pm S D) \\
(133)\end{array}$} & \multicolumn{4}{|c|}{ Positive cats (total number) - Mean ( \pm SD) } & \multicolumn{2}{|c|}{ Ectoparasite- Mean $( \pm$ SD) } \\
\hline & & $\begin{array}{l}\text { Any } \\
\text { pathogen } \\
(237)\end{array}$ & $\begin{array}{l}\text { Babesia spp. } \\
\text { (147) }\end{array}$ & $\begin{array}{l}\text { Hepatozoon spp. } \\
\text { (12) }\end{array}$ & $\begin{array}{l}\text { Hemoplasmas } \\
\text { (137) }\end{array}$ & $\begin{array}{l}\text { Non- } \\
\text { infestation } \\
(184)\end{array}$ & $\begin{array}{l}\text { Infestation } \\
\text { (188) }\end{array}$ \\
\hline$\overline{\mathrm{WBC}}\left(\times 10^{3} / \mu \mathrm{l}\right)$ & $19.68( \pm 8.7)$ & $18.92( \pm 7.4)$ & $19.25( \pm 7.7)$ & $19.57( \pm 5.5)$ & $18.12( \pm 6.9)^{* *}$ & $19.04( \pm 8.4)$ & $19.32( \pm 7.4)$ \\
\hline $\mathrm{RBC}\left(\times 10^{6} / \mu \mathrm{l}\right)$ & $7.4( \pm 1.4)$ & $7.576( \pm 1.5)$ & $7.7( \pm 1.4)$ & $7.1( \pm 1.7)$ & $7.38( \pm 1.6)$ & $7.69( \pm 1.4)$ & $7.39( \pm 1.6)^{* *}$ \\
\hline $\mathrm{HGB}(\mathrm{g} / \mathrm{dl})$ & $11.46( \pm 2.1)$ & $11.62( \pm 2.1)$ & $11.7( \pm 2.1)$ & $11.4( \pm 2.3)$ & $11.4( \pm 2.3)$ & $11.81( \pm 2)$ & $11.31(2.2)^{* *}$ \\
\hline $\mathrm{HCT}(\%)$ & $36( \pm 6.5)$ & $36.72( \pm 6.8)$ & $36.9( \pm 6.4)$ & $35.15( \pm 6.7)$ & $36.3( \pm 7.2)$ & $36.9( \pm 6.3)$ & $36.02( \pm 7.0)$ \\
\hline MCV (fl.) & $48.43( \pm 4.5)$ & $48.81( \pm 5.1)$ & $48.7( \pm 5.2)$ & $49.1( \pm 3.8)$ & $49.5( \pm 5.3)$ & $48.11( \pm 4.4)$ & $49.21( \pm 5.3)^{* *}$ \\
\hline $\mathrm{MCH}(\mathrm{pg})$ & $15.38( \pm 1.1)$ & $15.42( \pm 1.2)$ & $15.4( \pm 1.2)$ & $15.9( \pm 1.1)$ & $15.5( \pm 1.2)$ & $15.41( \pm 1.0)$ & $15.39( \pm 1.24)$ \\
\hline $\mathrm{MCHC}(\mathrm{g} / \mathrm{dl})$ & $31.88( \pm 2.2)$ & $31.72( \pm 2.3)$ & $31.7( \pm 2.1)$ & $32.4( \pm 0.9)$ & $31.5( \pm 2)$ & $32.13( \pm 1.9)$ & $31.42( \pm 2.2)^{* *}$ \\
\hline $\operatorname{PLT}\left(\times 10^{3} / \mu \mathrm{l}\right)$ & $438( \pm 169.3)$ & $401.7( \pm 146)^{* *}$ & $405.5( \pm 147.1)$ & $468.8( \pm 171.4)$ & $394( \pm 148.4)^{* *}$ & $412.58( \pm 149.3)$ & $\begin{array}{l}417.27( \pm \\
161.81)\end{array}$ \\
\hline
\end{tabular}

Abbreviations: WBC white blood cell; $R B C$ red blood cell; $H G B$ hemoglobin; $H C T$ hematocrit; $M C V$ mean corpuscular volume; $M C H$ mean corpuscular hemoglobin; $M C H C$ mean corpuscular hemoglobin concentration; PLT platelets

**Statistically significant differences $(P<0.05)$

cats tested [9]. Similarly, the prevalence of hemoplasmas (36.9\%;137/372) infection was higher in the cats in the current research compared to recent previous studies [17], while Hepatozoon $(3.2 \% ; 12 / 372)$ had a lower rate of the infection than the previous report [18]. The rate of Babesia and hemoplasmas in our study were similar to those described in other studies performed in Spain [12], Germany [19], Japan [20] and Iran [21]. In general, the differences in prevalence could have been due to several factors such as the varying nature of the cats being sampled in different studies (healthy versus sick/ hospitalized/ anemic populations/ pet versus feral), detection methods (conventional PCR with sequencing versus species-specific qPCR) and/or geographical variation [12]. The most prevalent co-infection of these VBPs in this study were with Babesia and hemotropic mycoplasma. It has been demonstrated that concurrent infection of Babesia with other hemoparasites, notably hemotropic mycoplasma species or Hepatozoon species, is common in endemic regions [22]. The finding regarding VBP co-infection in the current study supported this fact. Moreover, the present study was the first to confirm this important information which should enhance awareness and alert the authorities and veterinarians of the situation of VBP infection in the studied area.

Consistent with this survey, other reports have also noted that male cats and adult cats (older than 1 year) had a higher risk of hemoplasmas infection in the majority of prevalence studies carried out worldwide [12] [21]. It has been shown in several studies that male cats, especially if not neutered, have more aggressive interactions which may enhance transmission via infected blood, and adult animals have a greater chance of exposure to blood-sucking arthropods [11, 23]. Besides, the roaming cats have been reported to get more chances in close contact with wild animals which was considered as a potential source for many different infectious diseases [11]. However, our study and other investigations have failed to demonstrate the association of male or adult cats with Babesia infection and Hepatozoon infection [9].

The main and suspected vectors of Babesia and Hepatozoon are the brown dog tick, Rhipicephalus sanguineus and of hemoplasmas are the flea, Ctenocephalides felis [24], which are found in warm and temperate regions all over the world. The location chosen for sample collection in the current research at $13.7563^{\circ} \mathrm{N}, 100.501^{\circ} \mathrm{E}$ was in a region with relatively high temperatures and humidity year-round, with an average low temperature of $22.0{ }^{\circ} \mathrm{C}$ (https://en.wikipedia.org/wiki/Bangkok\#Climate). Consequently, this climate might support the development of a high variety of blood-feeding arthropods compared to other temperate areas [25]. The overall prevalence of ectoparasites found in our study was much lower than that described in former investigation in Thailand, where 95.8\% of 575 cats had ectoparasites [15]. Clearly, the campaigns of occasionally administering prophylactic vaccination and anti-ecto- and anti-endoparasitic drugs to stray dog and cat populations in this community since 2005 have had a considerable positive impact on zoonotic disease elimination and prevention [15]. The studied cats in this research were suffering from infestations with fleas, ticks and lice, of which fleas were the most common (46.5\%), followed by lice $(1.6 \%)$ and ticks $(0.8 \%)$, respectively. This finding was in agreement with similar studies done elsewhere, as fleas have been reported to be the predominant species parasitizing cats [15]. Thailand, a tropical country, has many different blood-sucking ectoparasites; in particular, infestation with the flea C. felis is common in cats [17, $24]$ and the current results re-enforced this. The flea $(C$. felis) has always been suspected as being the natural route 
Table 3 Different hematological findings of vector-borne infection in semi-domesticated cats

\begin{tabular}{|c|c|c|c|c|c|c|c|c|c|c|}
\hline \multirow[t]{2}{*}{ Hematology } & \multirow{2}{*}{$\begin{array}{l}\text { Total number } \\
\text { of cats }\end{array}$} & \multirow{2}{*}{$\begin{array}{l}\text { Number of negative } \\
\text { cats (\%) }\end{array}$} & \multicolumn{8}{|c|}{ Number of positive cats (\%) } \\
\hline & & & $\begin{array}{l}\text { Any } \\
\text { pathogen }\end{array}$ & $\begin{array}{l}\text { Babesia } \\
\text { spp. }\end{array}$ & Hemoplasmas & $\begin{array}{l}\text { Hepatozoon } \\
\text { spp. }\end{array}$ & $\begin{array}{l}\mathrm{BB}+ \\
\mathrm{HM}\end{array}$ & $\begin{array}{l}\mathrm{BB}+ \\
\mathrm{HP}\end{array}$ & $\begin{array}{l}\mathrm{HM}+ \\
\mathrm{HP}\end{array}$ & $\begin{array}{l}\mathrm{BB}+ \\
\mathrm{HM}+\mathrm{HP}\end{array}$ \\
\hline & 372 & $135(36.3)$ & $237(63.8)$ & $147(39.5)$ & $137(36.8)$ & $12(3.2)$ & $\begin{array}{l}50 \\
(13.4)\end{array}$ & $\begin{array}{l}3 \\
(0.8)\end{array}$ & $6(1.6)$ & $2(0.5)$ \\
\hline \multicolumn{11}{|l|}{$\mathrm{RBC}\left(\times 10^{6} \mu \mathrm{l}\right)$} \\
\hline High (> 10) & $16(4.3)$ & $5(31)$ & $11(69)$ & $8(50)$ & $4(25)$ & 0 & $1(6.2)$ & 0 & 0 & 0 \\
\hline $\begin{array}{l}\text { Normal (5- } \\
10)\end{array}$ & $339(91.1)$ & $124(36.6)$ & $215(63.4)$ & $134(39.5)$ & $125(36.9)$ & $11(3.2)$ & $\begin{array}{l}47 \\
(13.9)\end{array}$ & $\begin{array}{l}3 \\
(0.9)\end{array}$ & $5(1.5)$ & $2(0.6)$ \\
\hline Low $(<5)$ & $17(4.6)$ & $6(35.3)$ & $11(64.7)$ & $5(29.4)$ & $8(47.1)$ & $1(5.9)$ & $\begin{array}{l}2 \\
(11.8)\end{array}$ & 0 & $1(5.9)$ & 0 \\
\hline \multicolumn{11}{|l|}{ HGB (g/dl) } \\
\hline High (> 15) & $16(4.3)$ & $7(43.8)$ & $9(56.2)$ & $7(43.8)$ & $3(18.8)$ & 0 & $1(6.3)$ & 0 & 0 & 0 \\
\hline $\begin{array}{l}\text { Normal (9- } \\
15)\end{array}$ & $323(86.8)$ & $114(35.3)$ & $209(64.7)$ & $130(40.2)$ & $120(37.2)$ & $10(3.1)$ & $\begin{array}{l}44 \\
(13.6)\end{array}$ & $\begin{array}{l}3 \\
(0.9)\end{array}$ & $4(1.2)$ & $2(0.6)$ \\
\hline $\operatorname{Low}(<9)$ & $33(8.9)$ & $14(42.4)$ & $19(57.6)$ & $10(30.3)$ & $14(42.4)$ & $2(6.1)$ & $\begin{array}{l}5 \\
(15.2)\end{array}$ & 0 & $2(6.1)$ & 0 \\
\hline \multicolumn{11}{|l|}{ HCT (\%) } \\
\hline High (> 52) & $2(0.5)$ & $1(50)$ & $1(50)$ & 0 & $1(50)$ & 0 & 0 & 0 & 0 & 0 \\
\hline $\begin{array}{l}\text { Normal (30- } \\
52)\end{array}$ & $314(84.4)$ & $111(35.4)$ & $203(64.6)$ & $129(41.1)$ & $113(35.9)$ & $10(3.2)$ & $\begin{array}{l}42 \\
(13.4)\end{array}$ & $\begin{array}{l}3 \\
(0.9)\end{array}$ & $4(1.3)$ & $2(0.6)$ \\
\hline Low $(<30)$ & $56(15.1)$ & $23(41.1)$ & $33(58.9)$ & $18(32.1)$ & $23(41.1)$ & $2(3.6)$ & $\begin{array}{l}8 \\
(14.3)\end{array}$ & 0 & $2(3.6)$ & 0 \\
\hline \multicolumn{11}{|l|}{ MCV (fl.) } \\
\hline High (> 55) & $38(10.2)$ & $13(34.2)$ & $25(65.8)$ & $14(36.8)$ & $19(50)$ & $1(2.6)$ & $\begin{array}{l}8 \\
(21.1)\end{array}$ & $\begin{array}{l}1 \\
(2.6)\end{array}$ & $1(2.6)$ & $1(2.6)$ \\
\hline $\begin{array}{l}\text { Normal (39- } \\
55)\end{array}$ & $332(89.2)$ & $121(36.4)$ & $211(63.6)$ & $132(39.8)$ & $118(35.5)$ & $11(3.3)$ & $\begin{array}{l}42 \\
(12.7)\end{array}$ & $\begin{array}{l}2 \\
(0.6)\end{array}$ & $5(1.5)$ & $1(0.3)$ \\
\hline Low (<39) & $2(0.5)$ & $1(50)$ & $1(50)$ & $1(50)$ & 0 & 0 & 0 & 0 & 0 & 0 \\
\hline \multicolumn{11}{|l|}{$\mathrm{MCH}(\mathrm{pg})$} \\
\hline High (> 17.5) & $14(3.8)$ & $5(35.7)$ & $9(64.3)$ & $8(57.1)$ & $5(35.7)$ & $1(7.1)$ & $\begin{array}{l}4 \\
(28.6)\end{array}$ & $\begin{array}{l}1 \\
(7.1)\end{array}$ & $1(7.1)$ & $1(7.1)$ \\
\hline $\begin{array}{l}\text { Normal } \\
(12.5-17.5)\end{array}$ & 357 (96) & $129(36.1)$ & $228(63.9)$ & 139 (38.9) & $132(37)$ & $11(3.1)$ & $\begin{array}{l}46 \\
(12.9)\end{array}$ & $\begin{array}{l}2 \\
(0.6)\end{array}$ & $5(1.4)$ & $1(0.3)$ \\
\hline Low $(<12.5)$ & $1(0.3)$ & $1(100)$ & 0 & 0 & 0 & 0 & 0 & 0 & 0 & 0 \\
\hline \multicolumn{11}{|l|}{ MCHC (g/dl) } \\
\hline High (> 36) & $7(1.9)$ & $3(42.9)$ & $4(57.1)$ & $4(57.1)$ & 0 & 0 & 0 & 0 & 0 & 0 \\
\hline $\begin{array}{l}\text { Normal (30- } \\
36)\end{array}$ & $289(77.7)$ & $105(36.3)$ & $184(63.7)$ & $114(39.4)$ & 103 (35.6) & $12(4.2)$ & $\begin{array}{l}36 \\
(12.5)\end{array}$ & $\begin{array}{l}3 \\
(1.0)\end{array}$ & $6(2.1)$ & 2 \\
\hline Low $(<30)$ & $76(20.4)$ & $27(35.5)$ & $49(64.5)$ & $29(38.2)$ & $34(44.7)$ & 0 & $\begin{array}{l}14 \\
(18.4)\end{array}$ & 0 & 0 & 0 \\
\hline \multicolumn{11}{|l|}{ WBC $\left(\times 10^{3} \mu \mathrm{l}\right)$} \\
\hline High (> 14) & $280(75.3)$ & $102(36.4)$ & 178 (63.6) & $109(38.9)$ & $98(35)$ & $10(3.6)$ & $\begin{array}{l}34 \\
(12.1)\end{array}$ & $\begin{array}{l}1 \\
(0.4)\end{array}$ & $5(1.8)$ & $1(0.4)$ \\
\hline $\begin{array}{l}\text { Normal (5.5- } \\
\text { 14) }\end{array}$ & 89 (23.9) & $33(37.1)$ & $56(62.9)$ & $36(40.4)$ & $36(40.4)$ & $2(2.2)$ & $\begin{array}{l}14 \\
(15.7)\end{array}$ & $\begin{array}{l}2 \\
(2.2)\end{array}$ & $1(1.1)$ & $1(1.1)$ \\
\hline Low $(<5.5)$ & $3(0.8)$ & 0 & $3(100)$ & $2(66.7)$ & $3(100)$ & 0 & $\begin{array}{l}2 \\
(66.7)\end{array}$ & 0 & 0 & 0 \\
\hline \multicolumn{11}{|l|}{ PLT $\left(\times 10^{3} \mu \mathrm{l}\right)$} \\
\hline High (> 800) & $6(1.6)$ & $3(50)$ & $3(50)$ & $3(50)$ & $1(16.7)$ & 0 & $\begin{array}{l}1 \\
(16.7)\end{array}$ & 0 & 0 & 0 \\
\hline
\end{tabular}


Table 3 Different hematological findings of vector-borne infection in semi-domesticated cats (Continued)

\begin{tabular}{|c|c|c|c|c|c|c|c|c|c|c|}
\hline \multirow[t]{2}{*}{ Hematology } & \multirow{2}{*}{$\begin{array}{l}\text { Total number } \\
\text { of cats }\end{array}$} & \multirow{2}{*}{$\begin{array}{l}\text { Number of negative } \\
\text { cats (\%) }\end{array}$} & \multicolumn{8}{|c|}{ Number of positive cats (\%) } \\
\hline & & & $\begin{array}{l}\text { Any } \\
\text { pathogen }\end{array}$ & $\begin{array}{l}\text { Babesia } \\
\text { spp. }\end{array}$ & Hemoplasmas & $\begin{array}{l}\text { Hepatozoon } \\
\text { spp. }\end{array}$ & $\begin{array}{l}\mathrm{BB}+ \\
\mathrm{HM}\end{array}$ & $\begin{array}{l}\text { BB + } \\
\text { HP }\end{array}$ & $\begin{array}{l}\mathrm{HM}+ \\
\mathrm{HP}\end{array}$ & $\begin{array}{l}\mathrm{BB}+ \\
\mathrm{HM}+\mathrm{HP}\end{array}$ \\
\hline $\begin{array}{l}\text { Normal } \\
(800-300)\end{array}$ & $278(74.7)$ & $105(37.8)$ & $173(62.2)$ & $113(40.6)$ & $95(34.2)$ & $10(3.6)$ & $\begin{array}{l}37 \\
(13.3)\end{array}$ & $\begin{array}{l}3 \\
(1.0)\end{array}$ & $5(1.8)$ & $2(0.7)$ \\
\hline Low $(<300)$ & $88(23.7)$ & $27(30.7)$ & $61(69.3)$ & $31(35.2)$ & $41(46.6)$ & $2(2.3)$ & $\begin{array}{l}12 \\
(13.6)\end{array}$ & 0 & $1(1.1)$ & 0 \\
\hline
\end{tabular}

Abbreviations: WBC white blood cell; RBC red blood cell; $H G B$ hemoglobin; $H C T$ hematocrit; $M C V$ mean corpuscular volume; $M C H$ mean corpuscular hemoglobin; MCHC mean corpuscular hemoglobin concentration; PLT platelets; BB Babesia spp; HM Hemoplasmas; HP Hepatozoon spp *Statistically significant differences $(P<0.05)$

for hemoplasmas transmission; however, the attempts of the current study and of epidemiological study in proving the association between flea infestation and hemoplasmas infection have not been successful [12]. Interestingly, although the number of tick-infested cats was low, the prevalence of Babesia-infected cats in our study was large. Potentially, another route of transmission such as by blood exchange in fighting animals [26] or by vertically transplacental transmission [27] could have occurred and been involved in the spread of these pathogens in the current study.

While the most frequently described clinical signs in cats with hemoplasmosis are related to the occurrence of anemia [12, 28], the current study failed to demonstrate a statistical association between the hemoplasmas infection or any VBP infection with anemia, leukopenia, leukocytosis and thrombocytopenia. This finding was somewhat surprising but was in agreement with studies undertaken in stray cats in Italy [10] and in clientowner cats in Switzerland [29]. The clinical signs and laboratory findings for VBP infection depend on a wide range of factors. Concurrent diseases, previous infections or the species with distinct virulent of causative agents (e.g. Mycoplasma haemofelis, Candidatus Mycoplasma hemominutum, Candidatus Mycoplasma turicensis ) involved could considerably change these findings [12]. Specifically, Mhf and CMhm have been found to have the association with the existence of anemia in infected cats [12]. However, the present study has failed to identify the association between hemoplasma species and hematological changes due to the number of hemoplasma- infected samples which is representative for species identification was insufficient. Generally, younger dogs are more likely to develop clinical diseases in babesiosis and hepatozoonosis [22], yet this has been indiscernible in a cat population [22]. The level of parasitemia is usually low in cats infected with Hepatozoon, with less than $1 \%$ of the neutrophils containing gamonts [22]. If cats are able to tolerate more severe anemia than dogs, then the cats may act as a potential reservoir of VBPs without showing any specific clinical evidence [22, 30, 31].
An interesting outcome was the association between the laboratory hematological findings with the arthropod presence in cats. The hematological findings of the present study revealed decrease values of total erythrocyte hemoglobin concentration on the vector-borne infested cats compared with the negative group. A macrocytic hypochromic anemia represented by an increase in the MCV and a decline in the $\mathrm{MCHC}$ was determined in the ectoparasite-infested cat group compared to the non-infested group presented in this study. In agreement with our results, blood- sucking arthropods may play a role in the cause of blood-loss anemia in animals [32]. Ectoparasite infestation by ticks in some livestock animal has been reported to cause alterations in blood parameters including lower values for red blood cell count, packed cell volume, hemoglobin concentration and platelets count [33]. Furthermore, other factors such as nutritional status, co-infection of retrovirus (FIV, FeLV) and endoparasite infections are also known to affect hematocrit and hemoglobin levels in animals [34]. Further study is needed to improve those limitations.

\section{Conclusions}

The results indicated a high prevalence of VBP infection circulating in cats in the study area. There was a significant reduction in the hematological parameters of cats following ectoparasite burdens. The results also revealed out that macrocytic hypochromic type of anemic condition may occur in cats infested with ectoparasites in the study area. Further studies are recommended to be carried out in different parts of the country to further establish the effects of ectoparasite infestation on the hematological and pathological parameters in cats and other domestic animals. Campaigns of VBPs monitoring in Bangkok emphasizing on the investigation of vectors and possible routes of the infection in animals should be conducted to prevent the transmission of the pathogens.

\section{Methods}

Study areas and animal population

Animal population were calculated according to approval standard formula as previously described [21]. This study 
is focused on semi-domesticated cats dwelling in 53 monasteries belonging to 34 districts in the Bangkok Metropolitan Area. In total, 372 semi-domesticated cats were sampled between March to June in 2017.

\section{Sample and data collection}

Blood samples were collected for evaluation of hematological indicators and confirmation of VBPs was conducted using molecular method. Briefly, one milliliter of blood sample was obtained aseptically from the jugular vein of each cat and preserved in ethylene diamine tetra acetic acid (EDTA)-treated tubes. Subsequently, blood samples were used for hematological investigation and an aliquot was stored at $-20{ }^{\circ} \mathrm{C}$ until further use for molecular investigation. Data collection including age (animals $\leq 12$ months of age were considered juvenile, whereas all others were considered adult) and gender (male or female) were collected by interviewing from the caretakers in the monastery. Besides, all the cats were not administered anti-ectoparasite drugs before inspecting for the presence of ectoparasites (fleas, ticks or lices) by carefully combing for at least five minutes throughout its whole-body surface. All the species of ectoparasite were morphologically identified [35]. Animal ethic was approved by the Animal Ethics Committee of Kasetsart University, Bangkok, Thailand (ACKU60-VET006).

\section{Hematological investigation}

Cell blood count $(\mathrm{CBC})$ was performed within 24 hours after blood collection using a fully automatic hematology analyzer (Siemens Healthcare $\mathrm{GmbH}$, Germany) at the Veterinary Medicine Teaching Hospital of Kasetsart University (Bangkok, Thailand). Hematological abnormalities in the cats were determined regarding the presence or absence of anemia (Hematocrite; HCT $<30 \%$ ), leukopenia (White blood cells; WBC count $<5.5 \times 103$ / $\mu \mathrm{L})$, leukocytosis $(\mathrm{WBC}>14 \times 103 / \mu \mathrm{L}) \quad$ and thrombocytopenia (Platelet; PLT $<300 \times 103 / \mu \mathrm{L}$ ) [15]. The red blood cell (RBC) indices consisted of the mean corpuscular volume (MCV), mean corpuscular hemoglobin $(\mathrm{MCH})$ and mean corpuscular hemoglobin concentration (MCHC); these were used, whenever possible, to detect the type of anemia presenting in the infected cats. The reference interval of $\mathrm{CBC}$, anemia degree and anemia classification were employed following a previous study [11].

\section{PCR amplification and sequence analysis}

An E.Z.N.A. Blood DNA Mini Kit (Omega Biotek Inc., Norcross, Georgia, USA) was used for the DNA extraction from the whole blood samples. The DNA was assessed for quality at $260 / 280 \mathrm{~nm}$ and quantity at 260 / $230 \mathrm{~nm}$ using a spectrophotometer (Specord plus, Analytik Jena AG, Germany). In total, 372 samples of DNA were processed using the PCR protocol based on the amplification of a specific partial sequence of the $18 \mathrm{~S}$ rRNA gene of Babesia spp. and Hepatozoon spp. and of the $16 S$ rRNA gene of feline hemotropic mycoplasmas, respectively [36-38]. The sequences of primers used and the product size of the target gene specific for each vector-borne pathogen are shown in Table 4 . The reactions were performed in an automatic DNA thermal cycler MasterCycler Nexus Gradient (Eppendorf AG, Hamburg, Germany) including negative and positive controls for each sample. The PCR product was further visualized using ethidium bromide fluorescence after electrophoresis in a $1.5 \%$ agarose gel at $100 \mathrm{~V}$ for $40 \mathrm{~min}$. Subsequently, cats with negative PCR results for VBPs were indicated as the control group and cats with positive PCR results for VBPs were considered as the positive group.

For sequence analysis, selected positive amplicons were snipped from the gel and purified using FavorPrep ${ }^{\text {tm }}$ GEL/PCR Purification Kit (Favorgen, Ping-Tung Agricultural Biotechnology, Ping-Tung, Taiwan). Subsequently, the purified product was submitted for Sanger DNA sequencing (Macrogen, Seoul, Korea). After obtaining the sequence results, the sequences were compared with published isolates using the Basic Local Alignment Search Tool (BLAST) of the U.S. National Center for Biotechnology Information (https://blast.ncbi. nlm.nih.gov/Blast.cgi).

\section{Statistical analysis}

Statistical analysis of the findings obtained using PCR and the categorical variables of age, gender, presence of ectoparasite and hematological abnormalities (anemia, leukopenia, leukocytosis and thrombocytopenia) were analyzed using a chi-square test (cell frequency $>5$ ) or Fisher's exact test (cell frequency $\leq 5$ ). Any parameters statistically linked to positive PCR results were used in a logistic regression model with the odds ratio (OR) to test for independent risk factors associated with infection.

Descriptive statistics (mean, median, standard deviation (SD), minimum and maximum) were obtained for the continuous variables (RBC, Hemoglobin (HGB), HCT, MCV, MCH, MCHC, WBC, PLT count value). Distribution of the data for normality was assessed using the Kolmogorov-Smirnov test and subsequently a t-test or Mann-Whitney U test, respectively, were used to test differences between the feline vector-borne pathogen positive and negative cats depending on whether the data were normally distributed or not.

Significance was established at $P<0.05$. Both the $P$ value and the OR with a 95\% confidence interval (CI) were reported. Data were analyzed using the R software package for statistical analysis [39]. 
Table 4 Primer and protocols used for amplification of some vector-borne pathogens

\begin{tabular}{|c|c|c|c|c|}
\hline Organism & Target gene & Product size (bp) & PCR primers $\left(5^{\prime}-3^{\prime}\right)$ & Reference \\
\hline Babesia spp. & 18S rRNA & $422-440$ & $\begin{array}{l}\text { F: GTTTCTGMCCCATCAGCTTGA } \\
\text { R: CAAGACAAAAGTCTGCTTGAAAC }\end{array}$ & {$[36]$} \\
\hline Hepatozoon spp. & $18 \mathrm{~S}$ rRNA & $666-800$ & $\begin{array}{l}\text { F: ATACATGAGCAAAATCTCAAC } \\
\text { R: CTTATTATTCCATGCAG }\end{array}$ & {$[37]$} \\
\hline Hemoplasmas & $16 \mathrm{~S}$ rRNA & $595-618$ & $\begin{array}{l}\text { F: ATACGGCCCATATTCCTACG } \\
\text { R: TGCTCCACCACTTGTTCA }\end{array}$ & {$[38]$} \\
\hline
\end{tabular}

\section{Abbreviations}

VBPs: Vector-borne pathogens; PCR: Polymerase chain reaction; CBC: Cell blood count; RBC: Red blood cell; WBC: White blood cell; HGB: Hemoglobin HCT: Hematocrit; PLT: Platelet; MCV: Mean corpuscular volume; MCH: Mean corpuscular hemoglobin; MCHC: Mean corpuscular hemoglobin concentration; OR: Odd ratio; SD: Standard deviation; Cl: Confident interval; FIV: Feline immunodeficiency virus; FeLV: Feline leukemia virus

\section{Acknowledgements}

The authors thank those staffs and graduate students at the Department of Parasitology, Faculty of Veterinary Medicine, Kasetsart University, Bangkok, Thailand who helped during sample collection. In addition, the authors thank the monks, nuns and animal caretakers who participated and helped in this project.

\section{Authors' contributions}

TI planned and designed the experiment and data analysis and revised the manuscript. TD conducted the experiment, interpreted the results and drafted the manuscript. WC collected samples and identified ectoparasites. KK collected samples, conducted the experiment and revised the manuscript. All authors have read and approved the final manuscript.

\section{Funding}

This research is supported in part for laboratory expenses and Ms. Thom Do's scholarship to attend her master courses in Veterinary Parasitology by the Kasetsart University Scholarships for ASEAN for Commemoration of the 60th Birthday Anniversary of Professor Dr. Her Royal Highness Princess Chulabhorn Mahidol. The funding agency had no role in sample collection, conducting experiment, data analysis and manuscript writing.

\section{Availability of data and materials}

The datasets generated and/or analysed during the current study are available in the Sequence Read Archive database in NCBI and can be accessed through accession numbers MW377729-MW377733 and MW377923-MW377924.

\section{Ethics approval and consent to participate}

Written informed consent was obtained from monks, nuns or animal caretakers who took responsible for these animals prior to sample collection. All the procedures were carried out according to the guidelines of animal care and use under the Ethical Review Board of the Office of National Research Council of Thailand (NRCT) for the conduction of the scientific research. In addition, permission was granted by Kasetsart University's Institution Animal Care and Use Committee as shown in the approval number ACKU60-VET006.

\section{Consent for publication}

Not applicable.

\section{Competing interests}

The authors declare that they have no competing interests.

Received: 29 May 2020 Accepted: 29 December 2020

Published online: 18 January 2021

\section{References}

1. Otranto D, Dantas-Torres F. Canine and feline vector-borne diseases in Italy: current situation and perspectives. Parasit Vectors. 2010;3(1):2.
2. Alvarado-Rybak M, Solano-Gallego L, Millán J. A review of piroplasmid infections in wild carnivores worldwide: importance for domestic animal health and wildlife conservation. Parasit Vectors. 2016;9(1):538.

3. Bergmann M, Englert T, Stuetzer B, Hawley JR, Lappin MR, Hartmann K. Risk factors of different hemoplasma species infections in cats. BMC Vet Res. 2016;13(1):52.

4. Qurollo B. Feline Vector-Borne Diseases in North America. Vet Clin North Am Small Anim Pract. 2019;49(4):687-702.

5. de Caprariis D, Dantas-Torres F, Capelli G, Mencke N, Stanneck D, Breitschwerdt EB, et al. Evolution of clinical, haematological and biochemical findings in young dogs naturally infected by vector-borne pathogens. Vet Microbiol. 2011;149(1-2):206-12.

6. Hasanpour A, Moghaddam GA, Nematollahi A. Biochemical, hematological, and electrocardiographic changes in buffaloes naturally infected with Theileria annulata. Korean J Parasitol. 2008;46(4):223-7.

7. Silveira P, Damatta RA, Dagosto M. Hematological changes of chickens experimentally infected with Plasmodium (Bennettinia) juxtanucleare. Vet Parasitol. 2009;162(3-4):257-62.

8. Giannelli A, Latrofa MS, Nachum-Biala Y, Hodzic A, Greco G, Attanasi A, et al. Three different Hepatozoon species in domestic cats from southern Italy. Ticks Tick Borne Dis. 2017:8(5):721-4.

9. Simking P, Wongnakphet S, Stich RW, Jittapalapong S. Detection of Babesia vogeli in stray cats of metropolitan Bangkok, Thailand. Vet Parasitol. 2010; 173(1-2):70-5.

10. Spada E, Proverbio D, Galluzzo P, Della Pepa A, Bagnagatti De Giorgi G, Perego $R$, et al. Prevalence of haemoplasma infections in stray cats in northern Italy. ISRN microbiology. 2014;2014:298352.

11. Persichetti MF, Solano-Gallego L, Serrano L, Altet L, Reale S, Masucci M, et al. Detection of vector-borne pathogens in cats and their ectoparasites in southern Italy. Parasit Vectors. 2016;9(1):247.

12. Díaz-Regañón D, Villaescusa A, Ayllón T, Rodríguez-Franco F, García-Sancho M, Agulla B, et al. Epidemiological study of hemotropic mycoplasmas (hemoplasmas) in cats from central Spain. Parasit Vectors. 2018;11(1):140.

13. Latrofa MS, latta R, Toniolo F, Furlanello T, Ravagnan S, Capelli G, et al. A molecular survey of vector-borne pathogens and haemoplasmas in owned cats across Italy. Parasit Vectors. 2020;13:1-8.

14. Jittapalapong S, Pinyopanuwat N, Boonchob S, Chimnoi W, Jansawan W. A manual of regulation of animal rearing or yielding in the public land of Thailand: Ministry of Public Health. Kasetsart University Press, Bangkok. Thailand. 2003:250.

15. Jittapalapong S, Sangvaranond A, Inpankaew T, Pinyopanuwat N, Chimnoi W, Kengradomkij $C$, et al. Ectoparasites of stray cats in Bangkok metropolitan areas, Thailand. J Nat Sci. 2008;42:71-5.

16. Colella V, Nguyen VL, Tan DY, Lu N, Fang F, Zhijuan Y, et al. Zoonotic Vectorborne Pathogens and Ectoparasites of Dogs and Cats in Eastern and Southeast Asia. Emerg Infect Dis. 2020;26(6):1221.

17. Assarasakorn S, Veir JK, Hawley JR, Brewer MM, Morris AK, Hill AE, et al. Prevalence of Bartonella species, hemoplasmas, and Rickettsia felis DNA in blood and fleas of cats in Bangkok, Thailand. Res Vet Sci. 2012;93(3):1213-6.

18. Jittapalapong S, Rungphisutthipongse O, Maruyama S, Schaefer JJ, Stich RW. Detection of Hepatozoon canis in stray dogs and cats in Bangkok, Thailand. Ann N Y Acad Sci. 2006;1081:479-88.

19. Bergmann M, Englert T, Stuetzer B, Hawley JR, Lappin MR, Hartmann K. Risk factors of different hemoplasma species infections in cats. BMC Vet Res. 2017;13(1):52

20. Tanahara M, Miyamoto S, Nishio T, Yoshii Y, Sakuma M, Sakata Y, et al. An epidemiological survey of feline hemoplasma infection in Japan. J Vet Med Sci. 2010;72(12):1575-81. 
21. Ghazisaeedi F, Atyabi N, Zahrai Salehi T, Gentilini F, Ashrafi Tamai I, Akbarein $\mathrm{H}$, et al. A molecular study of hemotropic mycoplasmas (hemoplasmas) in cats in Iran. Vet Clin Pathol. 2014;43(3):381-6.

22. Day MJ. Arthropod-borne infectious diseases of the dog and cat. CRC Press; 2016

23. Ravagnan S, Carli E, Piseddu E, Da Rold G, Porcellato E, Zanardello C, et al. Prevalence and molecular characterization of canine and feline hemotropic mycoplasmas (hemoplasmas) in northern Italy. Parasit Vectors. 2017;10(1):132.

24. Bond R, Riddle A, Mottram L, Beugnet F, Stevenson R. Survey of flea infestation in dogs and cats in the United Kingdom during 2005. Vet Rec. 2007;160(15):503-6.

25. Hwang J, Gottdenker N, Oh DH, Lee H, Chun MS. Infections by pathogens with different transmission modes in feral cats from urban and rural areas of Korea. J Vet Sci. 2017;18(4):541-5.

26. Jefferies R, Ryan U, Jardine J, Broughton D, Robertson I, Irwin P. Blood, bull terriers and babesiosis: further evidence for direct transmission of Babesia gibsoni in dogs. Aust Vet J. 2007;85(11):459-63.

27. Fukumoto S, Suzuki H, Igarashi I, Xuan X. Fatal experimental transplacental Babesia gibsoni infections in dogs. Int J Parasitol. 2005;35(9):1031-5.

28. Raimundo JM, Guimaraes A, Botelho CF, Peixoto MP, Pires MS, Machado CH, et al. Hematological changes associated with hemoplasma infection in cats in Rio de Janeiro, Brazil. Rev Bras Parasitol Vet. 2016;25(4):441-9.

29. Willi B, Boretti FS, Baumgartner C, Tasker S, Wenger B, Cattori V, et al. Prevalence, risk factor analysis, and follow-up of infections caused by three feline hemoplasma species in cats in Switzerland. J Clin Microbiol. 2006; 44(3):961-9.

30. Ahantarig A, Trinachartvanit W, Milne J. Tick-borne pathogens and diseases of animals and humans in Thailand. Southeast Asian J Trop Med Public Health. 2008;39(6):1015.

31. Spada E, Proverbio D, Galluzzo P, Perego R, Bagnagatti De Giorgi G, Roggero N, et al. Frequency of piroplasms Babesia microti and Cytauxzoon felis in stray cats from northern Italy. Biomed Res Int. 2014;943754.

32. Biswal B, Misra S, Bisoi P. Effect of tick infestation at haematological parameters of cattle. J Vet Parasitol. 1988:2:9-13.

33. Barznji AA, Abdullah SH, Kadir MA-A. Evaluation of Haematological parameters in sheep infested with ticks in Sulaimani region. J Kirkuk U Agri Sci. 2014;5(2):1-7.

34. Springell P. Red cell volume and blood volume in beef cattle. Australian J Agri Res. 1968;19(1):145-60.

35. Wall RL, Shearer D. Veterinary ectoparasites: biology, pathology and control. 2nd ed. Blackwell Science; 2008

36. Hilpertshauser H, Deplazes P, Schnyder M, Gern L, Mathis A. Babesia spp. identified by PCR in ticks collected from domestic and wild ruminants in southern Switzerland. Appl Environ Microbiol. 2006;72(10):6503-7.

37. Otranto D, Dantas-Torres F, Weigl S, Latrofa MS, Stanneck D, Decaprariis D, et al. Diagnosis of Hepatozoon canis in young dogs by cytology and PCR. Parasit Vectors. 2011:4:55

38. Criado-Fornelio A, Martinez-Marcos A, Buling-Saraña A, Barba-Carretero JC. Presence of Mycoplasma haemofelis, Mycoplasma haemominutum and piroplasmids in cats from southern Europe: a molecular study. Vet Microbiol. 2003:93(4):307-17.

39. Pinheiro J, Bates D, DebRoy S, Sarkar D. R Core Team (2019). nlme: Linear and nonlinear mixed effects models. R Package Version 3.1-140. 2019.

\section{Publisher's Note}

Springer Nature remains neutral with regard to jurisdictional claims in published maps and institutional affiliations.

Ready to submit your research? Choose BMC and benefit from:

- fast, convenient online submission

- thorough peer review by experienced researchers in your field

- rapid publication on acceptance

- support for research data, including large and complex data types

- gold Open Access which fosters wider collaboration and increased citations

- maximum visibility for your research: over $100 \mathrm{M}$ website views per year

At BMC, research is always in progress.

Learn more biomedcentral.com/submissions 